\title{
Grzegorz Nowakowski
}

\section{Wyobraźnia wzrokowa Paula Celana - das Aug, dunkel}

ABSTRACT. Nowakowski Grzegorz, Wyobraźnia wzrokowa Paula Celana - das Aug, dunkel [The visual imagination of Paul Celan - das Aug, dunke/]. „Przestrzenie Teorii” 5, Poznań 2005, Adam Mickiewicz University Press, pp. 161-169. ISBN 83-232-1605-3. ISSN 1644-6763.

The article "The Visual Imagination of Paul Celan - das Aug, dunkel" raises the problem of the poet's search for language and "the place, from where you can see the best perspective". It shows the number of methodological dilemmas which inevitably result from analysing the visual imagination. It speaks of "the eye" understood as the crucial element of Celan's poetics. The author questions in his article the common percepcion of Celan as a poet of Shoah (as if) shifting the momentum to the eye. The eye, reduced in the very grammatical form of the word (Auge is turned into Aug), gives the unity to Celan's work. The eye, the restless wanderer, accompanies this poetry from the first to the last poem. The author of the article ventures to elucidate various aspects of the use of the organ of vision in Celan's poetry and draws a conclusion that the consistent theory of visual perception is central to Celan's work.

Imre Kertesz $\mathrm{w}$ mowie wygłoszonej w berlińskim RenaissanceTheater powiedział: „Lubię pisać po węgiersku, gdyż w ten sposób lepiej czuję niemożliwość pisania. Nawiasem mówiąc, są to słowa Kafki, który w swym liście pisanym do Maksa Broda, charakteryzując los żydowskiego pisarza, mówił o trzech niemożliwościach: niemożliwością jest niepisanie, niemożliwością jest pisanie po niemiecku i niemożliwością jest pisanie w jakimkolwiek innym języku. A potem dorzucił: «Właściwie mógłbym dodać jeszcze czwartą niemożliwość, a mianowicie tę, że niemożliwością jest też pisanie». Niewykluczone, że dzisiaj uzupełniłbym to jeszcze stwierdzeniem, że niemożliwością jest pisanie o Holocauście"1.

Uwaga węgierskiego noblisty oraz cytowana wypowiedź Kafki odnosi się nie tylko do żydowskich pisarzy. Kwestia języka to zagadnienie dotyczące większości powojennych twórców. Wystarczy przywołać nazwiska polskich poetów, Różewicza lub Herberta, aby uzmysłowić sobie, że stwierdzenie Adorno, iż ,jest barbarzyństwem napisać wiersz po Oświęcimiu” nie wiąże się jedynie z krytyką Fugi śmierci Celana, ale stosuje się do kondycji całej powojennej poezji, do największej trudności, jaka przed tą poezją stanęła. Twórczość tych, którzy przeżyli wojnę, dotyczy dramatu poszukiwania języka. Pytanie, w jakim stopniu jest to język

1 I. Kertesz, Język na wygnaniu, w: tegoż, Język na wygnaniu, Warszawa 2004, s. 183-184. 
własny, a w jakim zapożyczony, było jednym z najważniejszych w drugiej połowie dwudziestego wieku.

Elias Canetti, Żyd urodzony w Bułgarii, piszący po niemiecku, swoją książkę, w której zawarł wspomnienia z dzieciństwa i najwcześniejszej młodości, zatytułował Ocalony język. Canetti poświęca wiele uwagi wysiłkom, które wiążą się z nabywaniem języka; kreśli obraz apodyktycznej matki, która uczyła go niemieckiego. „Bolesna” to jedyne określenie, jakie przychodzi mi do głowy na opisanie tego rodzaju nauki.

Język, którym posługują się powojenni pisarze, zwłaszcza żydowscy, to język ocalonych. Ale ci, którym udało się przeżyć, nie znajdują języka, by opisać to, co się stało. Ich pisanie to w dużej mierze szukanie zagubionego języka.

Czesław Miłosz zauważył: „Każdy chyba człowiek przyjmuje nieszczęście w osłupieniu, jako coś, co absolutnie nie mogło się zdarzyć, a jednak się zdarzyło. Wydaje się ono pogwałceniem niepisanej umowy $\mathrm{z}$ istnieniem. Ufaliśmy tej umowie, zgodnie z którą, mimo że ludzie na ogół cierpią, my mieliśmy być oszczędzeni. Skoro umowa została pogwałcona, niech będzie przynajmniej wyższa instancja zdolna dosięgnąc karą kogoś (kogo?), kto umowę pogwałcił, i brak takiej instancji odczuwamy jako potworność. Krzyczymy - jak długo, to już zależy od naszego charakteru, temperamentu. Większość ludzi doświadcza tego przynajmniej raz w życiu na planie osobistym, przez utratę kochanej osoby, nieuleczalne dolegliwości albo przegraną w wykonywanym zawodzie. Jeżeli natomiast, co w naszym stuleciu nierzadkie, widziało się obce czołgi wjeżdżające w ulice rodzinnego miasta, zna się także inny rodzaj, publicznego, nieszczęścia. I ostatecznie wszystkie odmiany publicznego nieszczęścia sprowadzają się do nieszczęścia inwazji, dokonanej czy przeczuwanej, $\mathrm{z}$ zewnątrz albo $\mathrm{z}$ wewnątrz, tj. podboju bezbronnych przez zorganizowaną siłę"2.

Krzyku cierpienia w życiu nie można odzwierciedlić krzykiem w sztuce. Jak zatem zachować się wobec tego, co wydarzyło się w latach drugiej wojny światowej, i gdzie szukać języka? Jakiego języka?

Kertesz, więzień hitlerowskich obozów zagłady, poprzez pryzmat własnej biografii pokazuje losy ludzi uwikłanych w okrucieństwa drugiej wojny światowej. Holocaust, największa trauma współczesnej Europy, oraz problem języka, który miałby opisać to doświadczenie, jest głównym zagadnieniem jego twórczości. Dlatego ta twórczość koresponduje z liryką poety Szoahu, Paula Celana.

Celana i Kertesza (oraz cytowanego przez niego Kafkę) łączy wiele; wszyscy są Żydami, wszyscy tworzyli w XX wieku i każdy z nich przy-

${ }^{2}$ Cz. Miłosz, Ziemia Ulro, Kraków 2000, s. 147. 
szedł na świat w Europie Środkowowschodniej. Celan łączy się z Kerteszem poprzez niemożliwą próbę opisania grozy Zagłady, z Kafką dzieli doświadczenie pisania w języku niemieckim.

Paul Antschel, bo tak brzmi prawdziwe nazwisko Celana, urodził się w 1920 roku w Czerniowcach, w rodzinie, która na co dzień posługiwała się językiem niemieckim. Miasteczko, w którym przyszedł na świat, znajduje się w Europie Środkowowschodniej, na terenach zamieszkiwanych przez różnojęzyczną ludność, która podlegała silnym wpływom kultury niemieckiej. Sam poeta wspomniał o swoich korzeniach w przemówieniu wygłoszonym z okazji otrzymania Nagrody Literackiej Wolnego Hanzeatyckiego Miasta Bremy: „Okolice, z których ja - jakże okrężnymi drogami!, ale czy coś takiego w ogóle istnieje: drogi okrężne? - zatem okolice, z których przybywam do Państwa, mogą być większości z Was nieznane. Jest to krajobraz, w którym zadomowiła się wcale niemała część owych chasydzkich opowieści, opowiedzianych nam wszystkim przez Martina Bubera na nowo po niemiecku. Była to, jeśli wolno mi uzupełnić o parę szczegółów ten topograficzny szkic, jaki teraz z bardzo daleka staje mi przed oczyma, była to więc okolica, w której żyli ludzie i księgi”3.

Celan mówił o ojczyźnie, która została bezpowrotnie utracona. Pod koniec wojny wyjechał z rodzinnego miasta do Bukaresztu, skąd następnie uciekł do Austrii, nie chcąc pozostać w Rumunii. Niedługo potem wyjechał do Paryża, gdzie spędził resztę swojego życia.

W 1952 roku ukazała się książka Mak i pamięć, zawierająca między innymi słynną Fugé śmierci. Jest to właściwy debiut Celana, w którym poeta podejmuje tematy, które będzie konsekwentnie kontynuował w całej późniejszej twórczości. Zatrzymajmy się na chwilę nad tytułem zbioru. Symbolika maku w kulturze europejskiej jest wieloznaczna, lecz jest on przede wszystkim symbolem marzeń sennych oraz śmierci. To roślina, która wyznacza granicę między światem żywych i zmarłych. Jest także symbolem płodności ze względu na obfitą wegetację oraz liczbę ziaren zawartych $\mathrm{w}$ makówce. W niektórych kulturach do trumien wsypywano ziarna maku, aby umarli zajęli się ich liczeniem i nie mogli nachodzić żywych. Smierć i płodność łączą się w micie wegetacyjnym, podobnie jak w przypadku Demeter i Persefony. Zderzenie w tytule maku wywołującego obraz świata podziemnego, świata umarłych, rośliny przenoszącej w zaświaty oraz pamięci, jest odniesieniem do ofiar nazizmu, pierwszą próbą opisania Holocaustu podjętą przez Celana.

Celan w swoim przemówieniu zauważył: „Osiągalne, bliskie i nie utracone wśród tych strat pozostało jedno: język. On, język, nie zginął, tak, mimo wszystko. Ale musiał przejść przez własne niemożności odpo-

${ }^{3}$ P. Celan, Utwory wybrane, Kraków 2003, s. 315. 
wiedzi, przejść przez straszliwe zamilkanie, przez tysiące mroków niosących śmierć mowy. Przeszedł przez to i nie znalazł słów na to, co się wydarzyło, jednak szedł przez dzianie się. Przeszedł i dane mu było znowu wyjść na światło dzienne "wzbogaconym" o to wszystko.

W tym języku, w owych latach i w późniejszych także, próbowałem pisać wiersze: żeby mówić, żeby się zorientować, żeby zbadać, gdzie się znajduję, co ze mną się stało, i żeby zarysować sobie rzeczywistość" 4 .

Te słowa zostały wypowiedziane w 1958 roku. Każdy kolejny tom Celana jest nieustanną redukcją obrazów, coraz większym wotum nieufności wobec języka, przemianą, która podąża w stronę resztek. Wiersze stają się coraz krótsze, struktura zdań jest nieustannie rozbijana, przybierając formę stenogramu. Słowa są naznaczone niepełnością, coraz bardziej wyizolowane, wiersze zaczynają się rozsypywać.

Pod koniec kwietnia 1970 roku rozpacz przywiodła Celana nad brzegi Sekwany. Jego ciało odnaleziono w wodzie na początku maja. Poeta „wyzuty z namiotu” próbował poprzez język łączyć się z przeszłością, w której zostały Czerniowce i rodzina zabita w obozach koncentracyjnych. Mimo że znał wiele języków, zakorzenił się właśnie w niemieckim, który był równocześnie Muttersprache, jak i Mordsprache. Próbował znaleźć język, który przyniósłby „zmianę oddechu”, pozwalając dotrzeć do prawdy. Ale to ten sam poeta napisał w Nocq spowite:

$$
\begin{aligned}
& \text { Słowo - no wiesz: } \\
& \text { Takie zwłoki. } \\
& \text { Daj nam je umyć, } \\
& \text { Daj nam je czesać, } \\
& \text { Daj nam ich oko } \\
& \text { Zwrócić ku niebu }
\end{aligned}
$$

Cesare Ripa w swojej Ikonologii przedstawia Wyobraźnię jako kobietę, która unosi wzrok do góry. Zauważa też, że „Arystoteles w księdze De communi animalium motione mówi: Visio et imaginatio rerum agendarum vim obtinet, czyli że etymologicznie «wyobraźnia» pochodzi od zmysłu wzroku, jako najszlachetniejszego"6. U Celana to oko jest martwe, a w najlepszym razie okaleczone. Wyobraźnia wzrokowa tego poety to otchłań, w którą nie sposób zaglądać bez lęku.

Jak zauważył Alvin Rosenfeld7, jego samobójcza śmierć była „szokującą negacją świata książek i ludzi”. Rosenfeld stwierdził również:

4 Tamże, s. 315.

5 Tamże, s. 67.

${ }^{6}$ C. Ripa, Ikonologia, Kraków 1998, s. 486 i n.

${ }^{7} \mathrm{Http} / / /$ www.fzp.jewish.org.pl/celan.html (Cytowany fragment pochodzi z książki A. Rosenfelda, Podwójna śmierć. Rozważania o literaturze Holocaustu). 
„Śmierć Celana nastąpiła niemal w tym samym czasie, co śmierć Nelly Sachs, i wraz z odejściem tych dwojga ważnych poetów nastąpił zmierzch wielkiej tradycji żydowskich autorów piszących po niemiecku. Sam ten fakt nadaje szczególnego znaczenia samobójstwu Celana, gdyż dopóki żył i pisał, istniała pewna silna więź łącząca Żydów z niemieckojęzyczną kulturą, współtworzoną i wzbogacaną przez twórczość żydowskich pisarzy na przestrzeni ostatnich dwóch stuleci. Celan stanowił istotne ogniwo tego łańcucha i dramatyczny sposób, w jaki zostało ono zerwane, wywołuje echo prowadzące nas wstecz, aż do Heinego".

Utarła się opinia, że Celan jest przede wszystkim poetą Szoahu, poetą filozofem rozprawiającym się z językiem, z jego niemożliwościami. To niewątpliwie prawda, ale jego dzieło jest tak wyjątkowe i wieloznaczne, że nie można go ograniczać tylko do powyższych stwierdzeń.

Chciałbym spojrzeć na Celana jako na poetę oka. Bo chociaż jego dzieło jest wynikiem nieustannej transformacji powodowanej wzrastającą nieufnością do możliwości języka, istnieje tutaj także wyjątkowa stałość: pierwszoplanowym elementem tej poezji jest caly czas oko. Jego poezja to poszukiwanie miejsca, z którego widać najlepiej, obsesja oka jest widoczna we wszystkich tomach. Oko jest kluczowym, strategicznym elementem tej poezji.

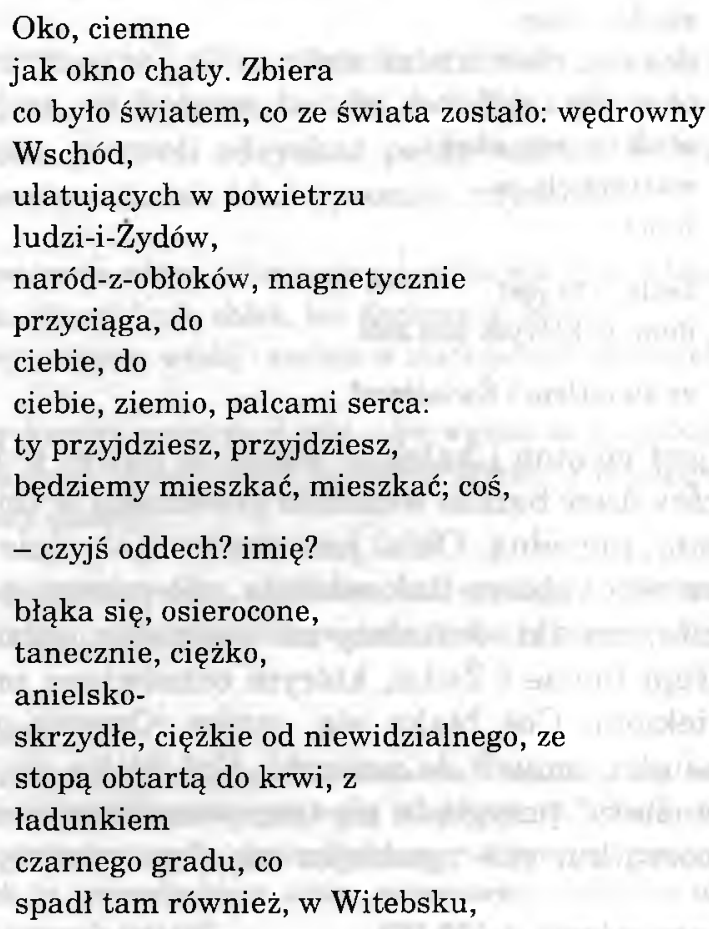




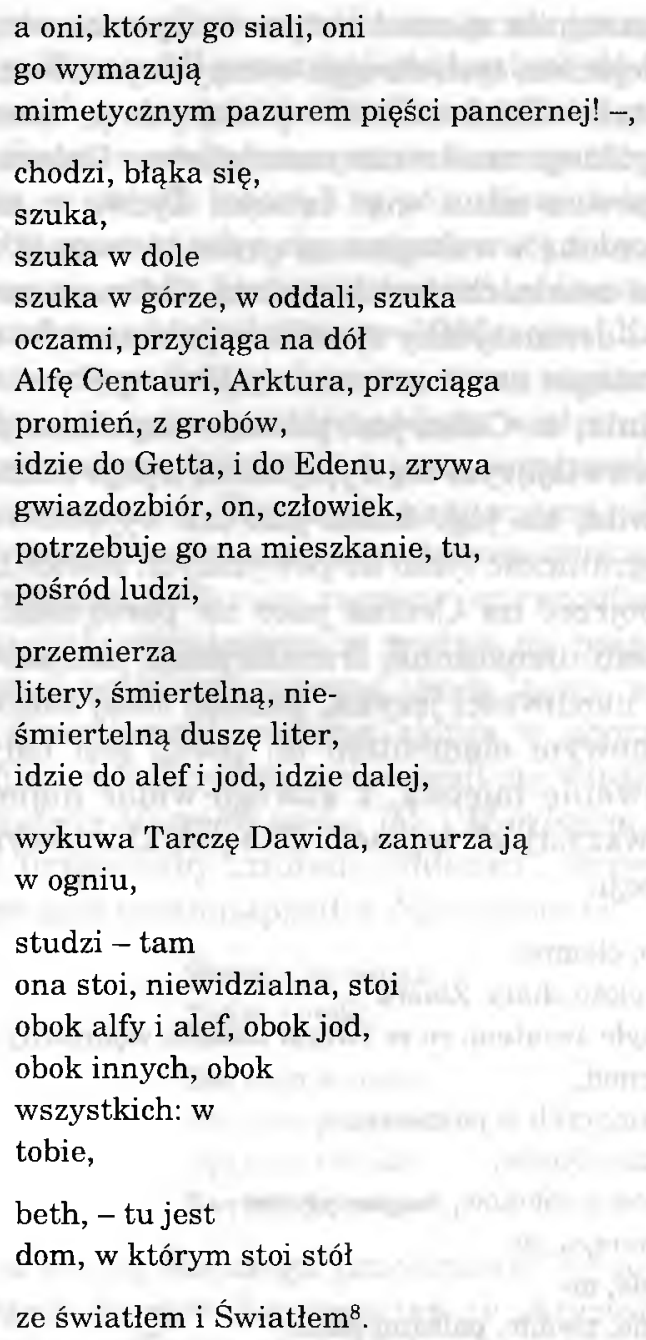

Oko Celana jest ciemne i kalekie. Widać to nawet $\mathrm{w}$ formie gramatycznej, bowiem das Auge bardzo wcześnie przechodzi w tej poezji w Aug, formę zredukowaną, niepelną. Ok(o) jest ciemne ,jak okno chaty”. Agramatyczne, ułomne ok(o) zbiera (tak właśnie, nie patrzy, a zbiera) to, co pozostało ze świata, resztki. Jesteśmy na wschodzie, gdzieś w Europie. W powietrze ulatują ludzie i Żydzi, którym odmówiono prawa do nazywania się człowiekiem. Coś błąka się, szuka. Czarny grad zniszczył ziemię, zabił nie-ludzi, zmusił do ucieczki. Coś błąka się, szuka. Ok(o) „ciemne jak okno chaty" przygląda się tym poszukiwaniom, towarzyszy im od samego początku, nie zgadzając się, by oprawcy wymazywali

8 P. Celan, Utwory wybrane, s. 159-160. 
śmierć, którą zadali. To ta sama śmierć, o której Celan napisze w Todesfuge: "der Tod ist ein Meister aus Deutschland sein Auge ist blau"9. Oko śmierci jest niebieskie, zdrowe, kompletne. W Fudze śmierci Żydzi kopią swój grób w powietrzu, w chmurach, gdzie „nie leży się ciasno”.

„Oddech”, „imię", które szuka chaty, przeszukuje zarówno groby, jak i gwiazdy, odwiedza Getto i Eden, „przemierza litery”. Alfa Centauri to jedna $\mathrm{z}$ najjaśniejszych gwiazd na niebie południowym, Arktur razem z Wegą z gwiazdozbioru Lutni są najjaśniejszymi gwiazdami nieba północnego ${ }^{10}$. Tarcza Dawida zostaje wykuta wśród nieśmiertelnej duszy liter, tych liter, z których składa się Pismo. To tutaj odnaleziony zostaje dom i stół „ze światłem i Światłem”. A więc nie niemiecki, tylko hebrajski; czy może raczej: nie tylko niemiecki, lecz przede wszystkim język Pisma.

Oko u Celana jest samotne, nieufnie przygląda się światu, językowi i samemu sobie. Jest tu wyraźna autotematyczność dotycząca organu wzroku. Oko stale spotyka jakieś inne oko, szuka spojrzenia drugiego, poddawane jest próbie, oglądane z zewnątrz i do wewnątrz. Uwaga Celana skupia się na oku, sposobach jego funkcjonowania, poszczególnych, anatomicznych częściach. Ściga go też cały czas oko innego, tego drugiego, czy raczej drugiej. Oko kobiece, które towarzyszy tej poezji od początku do końca.

Celan „przymierza” różne sposoby widzenia, pojedyncze oko tuła się, szukając miejsca, w którym będzie u siebie, gdzie spotka drugie oko, które, być może, pozwoli odzyskać pełny wzrok. W wierszu Marianna, który znajduje się w tomie Mak i pamięć, czytamy:

Są bez bzu twoje włosy, $\mathrm{z}$ lustrzanego szkła jest twoje oblicze.

Od oka do oka wędruje obłok, jak Sodoma do Babel:

jak listowie obrywa wieżę i szaleje w siarczanych zaroślach

Wtem błyskawica rozjarza ci usta - ów wąwóz ze szczątkami skrzypiec.

Śnieżnobiałymi zębami wodzi ktoś smyczkiem: O, niechaj piękniej

Zadźwięczy sitowie!

Ty także jesteś sitowiem, ukochana, a my wszyscy jesteśmy deszczem; niezrównanym winem jest twoje ciało, które spijamy w dziesięciu,

9 Tamże, s. 26.

$10 \mathrm{~W}$ tym samym tomie (die Niemandsrose) znajduje się wiersz Wykoronowany (umieszczony zaraz przed omawianym tutaj utworem). Pojawiają się tam warkocze Bereniki, które są odniesieniem do gwiazdozbioru położonego obok wspomnianych wyżej. Wszystkie $\mathrm{z}$ nich to gwiazdozbiory nieba wiosennego, kiedy na niebie można dostrzec największą ilość jasnych gwiazd. 
czółnem w zbożu twe serce, kierujemy je w stronę nocy.

dzbanuszek błękitu, tak leciutko przeskoczyłaś nad nami, gdyśmy spali...

Przed namiot nadciąga sotnia, a my cię żłopiąc niesiemy do grobu.

Snu twardy talar już brzęczy na kamiennej posadzce świata ${ }^{11}$.

Pod koniec wojny Celan zaczą intensywnie studiować pisma Martina Bubera, szczególnie chętnie sięgał do Opowieści chasydów. W polskim przekładzie autorstwa Pawła Hertza znajduje się opowieść z kręgu rabbiego Pinchasa z Korca Język $i$ języki: „Zapytano rabbiego Pinchasa: «Jak należy rozumieć, że ludzie przed budową wieży mieli jeden język i że dopiero kiedy Bóg go im pomieszał, każda z gromad otrzymała swój własny język? Jak to możliwe, by każdy z ludów nagle zamiast wspólnego posiadł odrębny język i mógł się w nim porozumieć?»

Rabbi Pinchas wyjaśnił: «Przed budową wieży wszystkie ludy miały jeden wspólny język święty, a oprócz niego każdy lud miał swój własny język. Dlatego powiedziano: Mieszkańcy calej ziemi mieli jednq mowę, a mianowicie świętą, i rozmaite języki, czyli odrębne, własne języki. W owych językach porozumiewali się z sobą członkowie owych ludów, w świętej mowie porozumiewały się ludy między sobą. Bóg, kiedy ich ukarał, odebral im ową świętą mowę»"12.

Czy nie o tym mówi Celan w Mariannie? Mówi o utracie języka, niemożliwości porozumienia, o obliczu z „lustrzanego szkła” i strzaskanych ustach. Pośród tych wszystkich niemożliwości wędruje obłok, Von Auge zu Aug, od oka do ok(a). Obłok wędruje ,jak Sodoma do Babel”, które korespondują z oczami. Jedno z nich jest pełne, drugie zredukowane do liczby najbardziej pojedynczej. Czyżby więc wszystko rozgrywało się pomiędzy oczyma? Na drodze przechodzenia od zadowolonej z siebie pełni do kalectwa? Jest to więc jedno oko, czy mamy tu też oko ukochanej? To oko jest oddzielone od ciała, samodzielne, ale umniejszone, noszące w sobie piętno straty. Das Auge oznacza w niemieckim także pączek, zarodek rośliny. Być może ta obsesyjna redukcja jest metaforą gnicia, rozkładu, jakiemu ulega pączek. Poezja Celana jest poezją embrionalną. Mam na myśli poetykę poszczególnych tomów, wierszy, całej twórczości wreszcie. To wiersze, które dopiero się stają, to paradoksalnie - nie ukończona całość, zapis dla uważnego czytelnika, w stronę którego kieruje się bezbronny wiersz.

Oko zawsze jest w ważnych miejscach tekstu, a wszystkie wiersze podążają w stronę resztek, stając się pod koniec pojemnikami na odpadki. Jaka bolesna przemiana zachodzi w tej liryce. Mak $i$ pamięć dzieli od

11 P. Celan, Utwory wybrane, s. 9.

12 M. Buber, Opowieści chasydów, Poznań 1986, s. 128. 
Zmiany oddechu (1967) i kolejnych książek przepaść. Jedno jest wszakże wspólne: oko. To w Zmianie oddechu Celan napisał:

OŚLEPNIJ już dziś:

wieczność jest też pełna oczu -

w nich

tonie to, co pomagało obrazom

pokonać drogę, którą przychodziły,

w nich

gaśnie to, co i ciebie odjęło

mowie, jednym ruchem,

co zaistniał z twej woli, jak

taniec dwóch słów, z czystej

jesieni, jedwabiu, nicości ${ }^{13}$.

Oczy wieczności likwidują granice i przeszkody, które stały się udziałem Celana. Tryb rozkazujący, który pojawia się w tym wierszu, nie pozostawia żadnych wątpliwości. „Oślepnij już dziś”, teraz, natychmiast. Patrzenie staje się coraz bardziej bolesne. W tym samym tomie $\mathrm{w}$ innym wierszu pojawia się określenie: „wzrokowe blizny”14.

Oko jest również literą; Celan po prostu pisze oczami. Im bardziej odkrywa niemożliwość pisania, tym bardziej odkrywa niemożliwość oka. Dlatego nieustannie egzaminuje ten organ, przyglądając mu się wciąż na nowo. I należałoby chyba powiedzieć, że tutaj oko nie tylko patrzy; ono jest przede wszystkim obserwowane, staje się celem spojrzenia. Pomimo tej presji, patrzy. Das Aug, dunkel...

Obecność oka, badanie jego aspektów medycznych i filozoficznych, implikuje teorię widzenia, którą Celan rozwija przez całą twórczość. To oko nie jest, jakbyśmy obrazowo powiedzieli, czubkiem piramidy, ale nicią wszytą w materię poetycką.

Ten krótki tekst jest bardziej stawianiem pytań niż dawaniem odpowiedzi. Pytań dotyczących wyobraźni wzrokowej poety jest wiele. Oko Celana zmusza nas do nieustannego szukania nowego spojrzenia na jego twórczość, podążania za wierszem, o którym Celan powiedział: „Wiersz jest samotny. Jest samotny i w drodze. Kto go pisze, jest wespół $z$ nim w drodze. Ale czy wiersz nie znajduje się przez to właśnie, a więc już tu, na spotkaniu - w tajemnicy spotkania?"15.

\footnotetext{
13 P. Celan, Utwory wybrane, s. 185.

14 Tamże, s. 187.

${ }^{15}$ P. Celan, Meridian, s. 335.
} 